medRxiv preprint doi: https://doi.org/10.1101/2021.06.09.21258571; this version posted June 12, 2021. The copyright holder for this preprint (which was not certified by peer review) is the author/funder, who has granted medRxiv a license to display the preprint in perpetuity.

\title{
Prevalence of uncoupling protein one genetic polymorphisms and their relationship with cardiovascular and metabolic health
}

Petros C. Dinas ${ }^{* 1,2}$ Eleni Nintou ${ }^{*},{ }^{1}$ Maria Vliora*, ${ }^{*}$ Paraskevi Sakellariou, ${ }^{1}$ Anna E. Pravednikova, ${ }^{3,4}$ Agata Witkowicz, ${ }^{5}$ Zaur M. Kachaev, ${ }^{3,12}$ Victor V. Kerchev, ${ }^{3,4}$ Svetlana N. Larina, ${ }^{3,4}$ James Cotton, ${ }^{6}$ Anna Kowalska, ${ }^{7}$ Paraskevi Gkiata, ${ }^{1}$ Alexandra Bargiota, ${ }^{8}$ Zaruhi A. Khachatryan, ${ }^{9}$ Anahit A. Hovhannisyan, ${ }^{9}$ Mariya A. Antonosyan, ${ }^{9}$ Sona Margaryan, ${ }^{9}$ Anna Partyka, ${ }^{5}$ Pawel Bogdanski, ${ }^{10}$ Monika Szulinska, ${ }^{10}$ Matylda Kregielska-Narozna, ${ }^{10}$ Rafał Czepczyński, ${ }^{11}$ Marek Ruchała, ${ }^{11}$ Anna Tomkiewicz, ${ }^{5}$ Levon Yepiskoposyan, ${ }^{9}$ Lidia Karabon, ${ }^{5}$ Yulii Shidlovskii, ${ }^{3,4,12}$ George S. Metsios, ${ }^{2}$ Andreas D. Flouris ${ }^{1}$

\section{"These authors contributed equally}

${ }^{1}$ FAME Laboratory, Department of Physical Education and Sport Science, University of Thessaly, Trikala, Greece.

${ }^{2}$ Faculty of Education Health and Wellbeing, University of Wolverhampton, Walsall, West Midlands, UK.

${ }^{3}$ Laboratory of Gene Expression Regulation in Development, Institute of Gene Biology, Russian Academy of Sciences, Moscow, Russia.

${ }^{4}$ Department of Biology and General Genetics, Sechenov First Moscow State Medical University (Sechenov University), Moscow, Russia.

${ }^{5}$ Institute of Immunology and Experimental Therapy, Polish Academy of Science, Wrocław, Poland.

${ }^{6}$ Royal Wolverhampton NHS Trust, New Cross Hospital, Wolverhampton, UK.

${ }^{7}$ Institute of Human Genetics, Polish Academy of Sciences, Poznań, Poland.

${ }^{8}$ Department of Endocrinology and Metabolic Diseases, Larissa University Hospital, Medical School, University of Thessaly, Larissa, Greece.

${ }^{9}$ Institute of Molecular Biology, National Academy of Sciences of the Republic of Armenia, Yerevan, Armenia

${ }^{10}$ Department of Treatment of Obesity, Metabolic Disorders and Clinical Dietetics, Poznan University of Medical Sciences, Poznań Poland

${ }^{11}$ Department of Endocrinology, Metabolism and Internal Medicine, University of Medical Sciences, Poznań, Poland.

NOTE: This preprint reports new research that has not been certified by peer review and should not be used to guide clinical practice. 
medRxiv preprint doi: https://doi.org/10.1101/2021.06.09.21258571; this version posted June 12, 2021. The copyright holder for this preprint (which was not certified by peer review) is the author/funder, who has granted medRxiv a license to display the preprint in perpetuity.

All rights reserved. No reuse allowed without permission.

${ }^{12}$ Center for Genetics and Life Science, Sirius University of Science and Technology, Sochi, Russia.

\section{ADDRESS FOR CORRESPONDENCE AND REPRINTS:}

Andreas D. Flouris

FAME Laboratory, Department of Physical Education and Sport Science,

University of Thessaly, Karies, Trikala, Greece

Tel: +302431047072

Fax: +302431047042

Email: andreasflouris@gmail.com 
medRxiv preprint doi: https://doi.org/10.1101/2021.06.09.21258571; this version posted June 12, 2021. The copyright holder for this preprint (which was not certified by peer review) is the author/funder, who has granted medRxiv a license to display the preprint in perpetuity.

\section{Abstract}

The contribution of UCP1 single nucleotide polymorphisms (SNPs) to susceptibility for cardiometabolic pathologies (CMP) and their involvement in specific risk factors for these conditions varies across populations. We tested whether UCP1 SNPS A3826G, A-1766G, Ala64Thr and A-112C are associated with the most common CMP (cardiovascular disease, hypertension, metabolic syndrome, and type-2 diabetes) and CMP risk factors. This case-control study included blood sample collection from 2,283 Caucasians (1,139 healthy; 1,144 CMP) across Armenia, Greece, Poland, Russia and United Kingdom for genotyping of the above-mentioned SNPs. We extended the results via a systematic review and meta-analysis, covering PubMed, Embase, and Cochrane Library databases. In Armenia the GA genotype and A allele of Ala64Thr were associated with 2-fold higher risk for CMP compared to the GG genotype or $G$ allele, respectively $(p<0.05)$. In Greece, A allele of Ala64Thr SNP decreased the risk of CMP by 39\%. Healthy individuals with A-3826G GG genotype and carriers of mutant allele of A-112C and Ala64Thr had higher body mass index compared to those carrying other genotypes. In healthy Polish, higher waist-to-hip ratio (WHR) was observed in heterozygotes A-3826G compared to AA homozygotes. Heterozygosity of the A-112C and Ala64Thr SNPs was related to lower WHR in CMP individuals compared to wild type homozygotes $(p<0.05)$. Meta-analysis in casecontrol studies showed no statistically significant odds ratios in different alleles across the four studied SNPs ( $p>0.05)$. Thus, we conclude that the studied SNPs could be associated with the most common CMP and their risk factors in some populations.

KEY WORDS: UCP1, metabolic health, polymorphism, BMI, WHR, meta-analysis 
medRxiv preprint doi: https://doi.org/10.1101/2021.06.09.21258571; this version posted June 12, 2021. The copyright holder for this preprint (which was not certified by peer review) is the author/funder, who has granted medRxiv a license to display the preprint in perpetuity.

\section{INTRODUCTION}

Single nucleotide polymorphisms (SNPs) in a number of candidate genes are highly implicated in energy balance as well as fat and glucose metabolism, modifying disease susceptibility (1-3). One of these candidate genes codes for uncoupling protein 1 (UCP1) which is expressed predominantly in brown adipose tissue, holding a critical role in oxidative phosphorylation and overall energy balance $(4,5)$. More than 2300 SNPs have been recognized within the UCP1 gene and its regulatory regions (6), but four have been commonly studied for their impact on metabolism and energy balance (7-11). These are: (i) A-3826G (rs1800592) located on the upstream region of $U C P 1$, (ii) A-1766G (rs3811791) a $2 \mathrm{~kb}$ upstream variant, (iii) A112C (rs10011540) on the 5'UTR region, and (iv) Ala64Thr (rs45539933) a missense variant.

The four UCP1 SNPs have been associated with a number of cardiometabolic pathologies (CMP) (12). The $G$ allele of $A-3826 G$ is more common in obese individuals $(13,14)$ and it is associated with increased body mass index (BMI), percent body fat, blood pressure (15), and high-density lipoprotein level (16). The same allele of this SNP is associated with higher BMI and glucose levels in overweight persons (17) and can increase the risk for proliferative diabetic retinopathy in individuals with type 2 diabetes (18). The other three SNPs are less prevalent but have been also associated with various risk factors for CMP $(6,7)$ : C allele of the $\mathrm{A}-112 \mathrm{C}$ is more frequent in individuals with type 2 diabetes than in healthy individuals (19), the Ala64Thr mutant allele is associated with higher waistto-hip ratio (WHR) (20), while the A-1766G SNP is related with obesity (9). Finally, the GAA haplotype (A-3826G, A-1766G, and Ala64Thr) is associated with decreased abdominal fat tissue, body fat mass, and WHR (21). 
medRxiv preprint doi: https://doi.org/10.1101/2021.06.09.21258571; this version posted June 12, 2021. The copyright holder for this preprint (which was not certified by peer review) is the author/funder, who has granted medRxiv a license to display the preprint in perpetuity.

The contribution of the four UCP1 SNPs to the susceptibility for CMP as well as their involvement in specific risk factors for these conditions varies across populations, even within the same race, probably due to environmental impacts. For instance, the frequency of $A G$ of $A-3826 G$ in persons with CMP ranges from $24 \%$ in Italy (22), to around $50 \%$ in Colombia (10), Japan (19), and Korea (16), and to $85 \%$ in China (18). Similarly wide frequency ranges have been reported also for the other three SNPs across different populations $(11,23-25)$. At the same time, some studies report that UCP1 SNPs are strongly associated with disease risk $(9,18,26)$, while others report no such findings (27-29). Therefore, it remains unclear if differences in the prevalence of these four UCP1 SNPs across different populations are associated with the prevalence of CMP.

Our incomplete understanding about the potential involvement of these four UCP1 SNPs in disease susceptibility limits the potential for precision medicine to effectively address CMP. An even more direct effect on disease mitigation is that CMP risk factors are currently addressed with equal importance across different populations, because clinicians remain unaware of the link between the four UCP1 SNPs and cardio-metabolic health in their country. In turn, this undermines the sustainability of healthcare systems due to limited efficacy of CMP prevention and mitigation guidelines. To address these important knowledge gaps, we investigated if differences in the frequency of A-3826G, A-1766G, Ala64Thr and A-112C SNPs across five countries (Armenia, Greece, Poland, Russia, United Kingdom) are associated with the most common CMP and their risk factors. To confirm any observed associations between the studied UCP1 SNPs and cardio-metabolic health, we extended our findings to consider all previously-studied populations by conducting a systematic review and meta-analysis. 
medRxiv preprint doi: https://doi.org/10.1101/2021.06.09.21258571; this version posted June 12, 2021. The copyright holder for this preprint (which was not certified by peer review) is the author/funder, who has granted medRxiv a license to display the preprint in perpetuity.

\section{METHODS}

\subsection{Case-control study}

This is a multicenter, multinational study conducted across five countries (Armenia, Greece, Poland, Russia, and United Kingdom) and funded by the European Commission (see Funding section). The participants were recruited via online and paper advertisements as well as word of mouth. Following approval from the relevant Bioethics Review Board in each country (see Online Supplement section 1.1.1). Written informed consent for participation was signed by the volunteers following detailed explanation of all the procedures and risks involved.

\subsubsection{Study design and data collection}

The study involved two groups of participants: individuals with CMP as well as healthy controls. We considered the following CMP, as they present with the highest prevalence $(30,31)$ amongst all health abnormalities related to cardio-metabolic health: cardiovascular disease, hypertension, metabolic syndrome, and type 2 diabetes. The inclusion criteria were: 1) adult; 2) diagnosed presence of CMP for the CMP group and generally healthy for the control group; 3) non-smokers, or have quit smoking for at least one year; 4) not in a pregnancy or lactation period; 5) no history of eating disorders; 6) no acute illness and/or infection during the last four weeks.

All participants were assessed for: 1) medical history via a structured interview-based questionnaire; 2) anthropometry (body height, body mass, WHR); 3) percent fat mass via non-invasive bioelectrical impedance analysis; 4) genotypes of the aforementioned four UCP1 SNPs detected in DNA isolated from blood samples. A detailed description of the adopted blood handling and genotyping methodologies 
medRxiv preprint doi: https://doi.org/10.1101/2021.06.09.21258571; this version posted June 12, 2021. The copyright holder for this preprint (which was not certified by peer review) is the author/funder, who has granted medRxiv a license to display the preprint in perpetuity.

is provided in the Online Supplement (Section 1.1.2). All participants were instructed, for 12 hours prior to assessments, to avoid the consumption of food, coffee, or alcohol and to refrain from exercise. Also, they were advised to consume two glasses of water about two hours prior to their assessment.

\subsubsection{Statistical analysis}

The data were analyzed using a general genetic model as previously described $(32,33)$. We calculated Hardy-Weinberg equilibrium to ensure unbiased outcomes (34). Linkage disequilibrium between genetic loci, haplotype analysis, and allele frequencies estimation were performed via the SHEsis platform $(35,36)$. We used chi-square tests to determine differences in UCP1 SNPs between groups, as well as Phi indices to report effect sizes (37). Also, we calculated odds ratios (OR) to determine associations of genotypes and alleles between groups in the overall sample as well as based on country (Online Supplement, Section 1.1.3). Finally, we used Kruskal Wallis ANOVA with post hoc Mann-Whitney $U$ tests to assess differences in BMI, WHR, and fat percentage between genotype groups for each UCP1 SNP. The level of statistical significance for the Hardy-Weinberg equilibrium was set at $p<0.05$ and for all other analyses at $p \leq 0.05$. Unless stated otherwise, the SPSS 26.0 (SPSS Inc., Chicago, IL, USA) software was used to perform the statistical analyses.

\subsection{Systematic review and meta-analysis}

We conducted a systematic review and meta-analysis (PROSPERO review protocol: CRD42019132376) investigating if differences in the frequency of A-3826G, A-1766G, Ala64Thr and A-112C SNPs are associated with the prevalence of the 
medRxiv preprint doi: https://doi.org/10.1101/2021.06.09.21258571; this version posted June 12, 2021. The copyright holder for this preprint (which was not certified by peer review) is the author/funder, who has granted medRxiv a license to display the preprint in perpetuity.

studied CMP. Following the Preferred Reporting Items for Systematic Reviews and Meta-analyses (PRISMA) guidelines (38), we searched the titles and abstracts in PubMed central, Embase, and Cochrane Library (trials) databases from the date of their inception to February 23, 2021, for studies that evaluated the prevalence of UCP1 A-3826G, A-1766G, Ala64Thr and A-112C SNPs and their association with CMP. No date, participants' health status, language, or study design limits were applied. A detailed description of the systematic review methodology and the searching algorithm is provided in the Online Supplement (Section 2.1).

\section{RESULTS}

\subsection{Case-control study}

The study population included 2283 Caucasian individuals (Table 1). Our Hardy-Weinberg equilibrium (HWE) analysis for the A-1766G revealed significant deviation in healthy individuals $\left(x^{2}=33.34, p<0.001\right)$, indicating that this SNP should be excluded from further analysis (34), for other UCP1 SNPs no deviation from HWE in healthy individuals was noticed. The frequencies of alleles and genotypes for the studied UCP1 SNPs in healthy controls and in CMP individuals are shown in Figure 1, Table 2 and Tables S4-S11. Odds ratios for the association between genotype and health status (i.e., healthy vs. CMP individuals) for each of the four studied UCP1 SNPs are shown in Table 2 and Tables S10-S11.

With regard to country-level stratification, allele frequency analysis (Tables S4-S9) in the Greek population showed that individuals carrying the $C$ allele of the A112C SNP or the A allele of the Ala64Thr SNP are $37 \%$ and $39 \%$ less likely to develop CMP, respectively ( $p<0.05$; Table S6). Moreover, the $G$ allele of the A- 
medRxiv preprint doi: https://doi.org/10.1101/2021.06.09.21258571; this version posted June 12, 2021. The copyright holder for this preprint (which was not certified by peer review) is the author/funder, who has granted medRxiv a license to display the preprint in perpetuity.

All rights reserved. No reuse allowed without permission.

3826G SNP was associated with $23 \%$ lower risk to develop CMP in the Polish population (Table S7).

In total, we found no associations between genotype and health status in the overall sample for the studied UCP1 SNPs $(p>0.05)$. Though, we observed an association between genotype and health status for Ala64Thr within the Armenian population, where the GA genotype was carried by $24.4 \%$ of the CMP individuals but only by $13.5 \%$ of healthy individuals. Also, the GA genotype of Ala64Thr showed a 2fold higher risk $(p=0.03)$ for CMP than the $G G$ genotype in the Armenian population (Table 2).

\subsubsection{Linkage Disequilibrium}

Our analysis for all four SNPs in this study in CMP individuals and healthy controls showed that the A-3826G and Ala64Thr were in strong linkage disequilibrium with a D' value of 0.831 . Similar results were observed for the combinations of $\mathrm{A}-3826 \mathrm{G}$ and $\mathrm{A}-112 \mathrm{C}$, as well as for the Ala64Thr and $\mathrm{A}-112 \mathrm{C}$ which were in strong linkage disequilibrium with D' values of 0.917 and 0.924 , respectively. However, the $r^{2}$ values for the combinations of A-3826G and Ala64Thr $\left(r^{2}=0.165\right)$ as well as $A-3826 G$ and $A-112 C\left(r^{2}=0.195\right)$ were relatively low, indicating that their effects are independent of each other. In contrast, the $r^{2}$ value for Ala64Thr and $A-112 C$ was high $\left(r^{2}=0.848\right)$, indicating a direct link between these two SNPs. Country-specific analysis of linkage disequilibrium between investigated SNPs can be found in Figures S1-2.

\subsubsection{Haplotype analysis}


medRxiv preprint doi: https://doi.org/10.1101/2021.06.09.21258571; this version posted June 12, 2021. The copyright holder for this preprint (which was not certified by peer review) is the author/funder, who has granted medRxiv a license to display the preprint in perpetuity.

In the overall sample, the haplotype analysis revealed that CMP individuals were $24 \%$ less likely to carry the GAC (A-3826G, Ala64Thr, A-112C) haplotype compared to healthy controls $(6.5 \%$ vs $8.5 \% ; p=0.023$; Table S1). Country-specific analysis showed lower CMP risk for this haplotype across countries but this association reached statistical significance only in the Greek population $(\mathrm{OR}=0.56$, Cl95\%: 0.34-0.91, $\mathrm{p}=0.017$ ). Additionally, in the Polish population, we found a higher frequency of the AGA haplotype in CMP individuals compared to healthy persons (74.9\% vs $70.6 \%)$, which indicates the relationship between this haplotype and higher risk of $\mathrm{CMP}(\mathrm{OR}=1.33, \mathrm{Cl} 95 \%$ : 1.03-1.73, $\mathrm{p}=0.032)$. On the contrary, for GGA haplotype we found a lower frequency in CMP Polish population compared to healthy individuals (15.6\% vs $20.3 \%$ ) indicating a protective effect in healthy individuals (OR=0.74, Cl95\%: 0.55-0.99, $\mathrm{p}=0.047$ ). In the Armenian population, the AA haplotype (A-3826G, Ala64Thr) increased the CMP risk more than 4-fold (OR=4.10, Cl95\%: 1.12-14.98, $\mathrm{p}=0.02$ ), while the $A G$ haplotype decreased the susceptibility to CMP $(\mathrm{OR}=0.65, \mathrm{C} \mid 95 \%=0.45-0.95, \mathrm{p}=0.025)$. The AA haplotype differs from the AG in the second position defined by the mutant allele of Ala64Thr confirming the association of A allele of this SNP with CMP risk. Detailed results for haplotype analysis for each country are provided in Tables S1-2.

\subsubsection{Association between UCP1 SNPs with specific CMP risk factors}

In healthy individuals, we observed significantly higher BMI in the homozygotes $G G$ of $A-3826 G$ as compared to $A A$ and $A G$ individuals $(p=0.03)$ as well as in carriers of the mutant allele of $A-112 C(p=0.015)$, and Ala64Thr $(p=0.004)$ compared to the wild type homozygotes (Table 3). We also showed that CMP 
medRxiv preprint doi: https://doi.org/10.1101/2021.06.09.21258571; this version posted June 12, 2021. The copyright holder for this preprint (which was not certified by peer review) is the author/funder, who has granted medRxiv a license to display the preprint in perpetuity.

individuals being heterozygotes of A-112C and Ala64Thr had lower WHR than wild type homozygotes (Table 3). Country-specific analysis showed that in the healthy Greek population, heterozygous individuals of A-112C and Ala64Thr displayed higher $\mathrm{BMI}$ and fat mass compared to the wild type homozygotes (BMI $p=0.005$, body fat $p=0.008$ and $B M I p=0.002$, body fat $p=0.005$, respectively; Table S14). In the Polish healthy population, mutant homozygotes of the A-112C SNP presented higher BMI compared to heterozygotes and wild type homozygotes (Table S12; $\mathrm{p}<0.05)$. Due to linkage disequilibrium between $\mathrm{A}-112 \mathrm{C}$ and Ala64Thr, the same effect was observed for mutant homozygotes of Ala64Thr. Finally, in Polish healthy individuals, higher WHR was observed in GA heterozygotes $(p=0.03)$ in comparison to wild type homozygous subjects (Table S12).

\subsection{Systematic review and meta-analysis}

\subsubsection{Searching procedure}

The searching procedure retrieved 817 publications of which 109 were duplicates. We excluded 219 publications being reviews, editorials, and conference proceeding as well as 161 publications which referred to animal studies. From the 328 remaining publications, 276 were excluded as they did not meet the inclusion criteria. In total, 52 eligible publications were included in the analysis. Detailed searching procedure results can be found in a PRISMA flowchart (Figure S3).

\subsubsection{Characteristics of included studies and risk of bias assessment}

The 52 eligible publications included in the analysis were published between 1998 and 2020 and included data from 24 different countries. The extracted data for 
medRxiv preprint doi: https://doi.org/10.1101/2021.06.09.21258571; this version posted June 12, 2021. The copyright holder for this preprint (which was not certified by peer review) is the author/funder, who has granted medRxiv a license to display the preprint in perpetuity.

all 52 included publications can be found in Table S17. The risk of bias assessment demonstrated low risk for the vast majority of the eligible studies (Online Supplement Section 2.2).

\subsubsection{Meta-analysis outcomes}

Fifty-one out of the 52 eligible publications were used for prevalence metaanalyses, while 22 eligible publications were used for odds ratios meta-analyses. The results from the meta-analyses are summarized in Figure 1 and Table 4, while the SNP-specific forest and funnel plots for the prevalence (Figures S5-24, S35-44) and the odds ratios (Figures S25-34, S45-S49) can be found in the Online Supplement (Sections 2.2.1 and 2.2.2). On the whole, for the different genotypes and alleles we performed 24 prevalence meta-analyses and 12 odds ratios metaanalyses which included a total of 34,313 cases. No statistically significant differences were observed in the prevalence of the mutant alleles of the four different SNPs ( $p>0.05$; Figure 1). Also, when we considered only case-control studies, we found no statistically significant odds ratios in different alleles across the four studied SNPS $(p>0.05)$.

\section{DISCUSSION}

Our findings confirm an association between the studied UCP1 SNPs and cardio-metabolic health in a multi-country sample of 2,283 persons as well as in a systematic review and meta-analysis that considers all previously-studied populations, a total of 34 thousand people across 24 countries. Furthermore, we found that differences in the distribution of genotypes and alleles of the studied SNPs between CMP individuals and healthy controls are associated with the 
medRxiv preprint doi: https://doi.org/10.1101/2021.06.09.21258571; this version posted June 12, 2021. The copyright holder for this preprint (which was not certified by peer review) is the author/funder, who has granted medRxiv a license to display the preprint in perpetuity.

prevalence of one or more of the most common CMP and their risk factors, in some (Armenia, Greece, and Poland) but not all (Russia and United Kingdom) countries.

Within our study population, the A-3826G (AG) was the most prevalent of the four SNPs studied in persons with CMP was $40 \%$, ranging from $34 \%$ in the UK to $42 \%$ in Armenia and $42 \%$ in Russia. This is very similar to the $43 \%$ found in our meta-analysis, and mid-way between the $29 \%$ reported in Spain (15) and the $\approx 50 \%$ reported in Colombia (10), Japan (19), and Korea (16). Our findings in the casecontrol study indicate that the A-3826G is not associated with CMP, but that it leads to increased BMI within the healthy population. Thus, it may promote the development of CMP in the presence of environmental factors (39) as well as other genetic traits (40).

Our results for Ala64Thr and A-112C indicate a strong linkage disequilibrium between the two SNPs. In our study the mutant A allele of Ala64Thr was detected in $9 \%$ of both healthy individuals and persons with CMP, and this frequency was not very different across the five studied countries. This was similar to the $7 \%$ for healthy individuals and $9 \%$ for CMP individuals found in our meta-analysis that included data from 4,984 persons across nine countries. Our observed prevalence rates for the $C$ allele of $\mathrm{A}-112 \mathrm{C}$ were $9 \%$ in healthy persons and $8 \%$ in individuals with CMP. This was somewhat lower than the $12 \%$ prevalence found in our meta-analysis that included data from 6,153 persons across eight countries. In terms of health impacts, our results demonstrate that the Ala64Thr and A-112C are associated with opposing effects in healthy individuals and persons with CMP. Specifically, we found that healthy individuals carrying the mutant alleles display higher BMI and, in some countries, body fat percent. On the other hand, persons with CMP who carry the mutant variants have lower WHR. These results partly reflect those reported in 
medRxiv preprint doi: https://doi.org/10.1101/2021.06.09.21258571; this version posted June 12, 2021. The copyright holder for this preprint (which was not certified by peer review) is the author/funder, who has granted medRxiv a license to display the preprint in perpetuity.

All rights reserved. No reuse allowed without permission.

previous studies $(21,41)$. For instance, the presence of mutant alleles Ala64Thr and A-1766G, in combination with A-3826G, can augment the beneficial effects of caloric restriction resulting in greater reductions in WHR (21).

Our findings indicate potential limitations of common analysis of different races, ethnicities, and regions when analyzing our data as an entire sample or via meta-analytic methods. For instance, the frequency of A allele of Ala64Thr across all our studied countries was $9 \%$, similar to the $8 \%$ found in our meta-analysis, in both cases suggesting no differences between healthy persons and individuals with CMP. However, our country-specific analysis demonstrated that the prevalence of A allele of Ala64Thr was significantly higher in healthy individuals across the Armenian $(27.9 \%)$ and the Greek (10.3\%) populations, as compared to CMP persons. Considering risk factors, we detected a number of associations with the four studied SNPs across Greece, Armenia and Poland, which were not observed in the other countries. Taken together, these findings suggest that the studied SNPs may be important for promoting risk factors and pathophysiological mechanisms involved in CMP, but that this involvement may be stronger in some races, ethnicities, and/or regions.

We conclude that, in some populations, the A-3826G, A-1766G, Ala64Thr and A-112C SNPs UCP1 SNPs may be associated with the prevalence of one or more of the most common CMP and their risk factors. Future studies on these SNPs may shed more light on the genetics of CMP and may uncover potential candidates for precision medicine. 
medRxiv preprint doi: https://doi.org/10.1101/2021.06.09.21258571; this version posted June 12, 2021. The copyright holder for this preprint (which was not certified by peer review) is the author/funder, who has granted medRxiv a license to display the preprint in perpetuity.

\section{ACKNOWLEDGMENTS}

The authors are grateful to Monika Jasek, Marta Wagner, and Eleftheria Barmpa for their support during the data collection and analysis.

\section{CONFLICT OF INTEREST}

The authors declare no conflict of interest.

\section{FUNDING}

The case-control study was supported by funding from the European Union $7^{\text {th }}$ Framework Program (FP7-PEOPLE-2013-IRSES Grant No. 319010; U-GENE project). The case-control study also received funding by the Russian Foundation for Basic Research (grant 19-34-51003). The Polish research center has received additional funding for the case-control study from the Polish Ministry of Science and Higher Education 2016-2017 international project co-financed W15/7.PR/2016.

\section{REFERENCES}

1. Groop L. Genetics of the metabolic syndrome. Br J Nutr. 2000;83 Suppl 1:S39-48.

2. Mirkov S, Myers JL, Ramírez J, Liu W. SNPs affecting serum metabolomic traits may regulate gene transcription and lipid accumulation in the liver. Metabolism. 2012;61(11):1523-7.

3. Shastry BS. SNP alleles in human disease and evolution. Journal of human genetics. 2002;47(11):561-6.

4. Dinas PC, Valente A, Granzotto M, Rossato M, Vettor R, Zacharopoulou A, et al. Browning formation markers of subcutaneous adipose tissue in relation to resting energy expenditure, physical activity and diet in humans. Hormone molecular biology and clinical investigation. 2017;31(1). 
medRxiv preprint doi: https://doi.org/10.1101/2021.06.09.21258571; this version posted June 12, 2021. The copyright holder for this preprint (which was not certified by peer review) is the author/funder, who has granted medRxiv a license to display the preprint in perpetuity.

All rights reserved. No reuse allowed without permission.

5. Valente A, Jamurtas AZ, Koutedakis $Y$, Flouris AD. Molecular pathways linking nonshivering thermogenesis and obesity: focusing on brown adipose tissue development. Biol Rev Camb Philos Soc. 2015;90(1):77-88.

6. Flouris $A D$, Dinas PC, Valente A, Andrade CMB, Kawashita NH, Sakellariou P. Exercise-induced effects on UCP1 expression in classical brown adipose tissue: a systematic review. Horm Mol Biol Clin Investig. 2017;31(2).

7. Pravednikova AE, Shevchenko SY, Kerchev VV, Skhirtladze MR, Larina SN, Kachaev ZM, et al. Association of uncoupling protein (Ucp) gene polymorphisms with cardiometabolic diseases. Molecular Medicine. 2020;26(1):51.

8. Jia JJ, Tian YB, Cao ZH, Tao LL, Zhang X, Gao SZ, et al. The polymorphisms of UCP1 genes associated with fat metabolism, obesity and diabetes. Mol Biol Rep. 2010;37(3):1513-22.

9. Chathoth S, Ismail MH, Vatte C, Cyrus C, Al Ali Z, Ahmed KA, et al. Association of Uncoupling Protein 1 (UCP1) gene polymorphism with obesity: a case-control study. BMC Med Genet. 2018;19(1):203.

10. Franco-Hincapie L, Duque CE, Parra MV, Gallego N, Villegas A, Ruiz-Linares A, et al. [Association between polymorphism in uncoupling proteins and type 2 diabetes in a northwestern Colombian population]. Biomedica. 2009;29(1):108-18.

11. Lim JH, Ko MM, Moon T-W, Cha MH, Lee MS. Association of the UCP-1 single nucleotide polymorphism A-3826G with the dampness-phlegm pattern among Korean stroke patients. BMC Complement Altern Med. 2012;12:180-.

12. Brondani LA, Assmann TS, Duarte GC, Gross JL, Canani LH, Crispim D. The role of the uncoupling protein 1 (UCP1) on the development of obesity and type 2 diabetes mellitus. Arquivos brasileiros de endocrinologia e metabologia. 2012;56(4):215-25.

13. Ramis JM, Gonzalez-Sanchez JL, Proenza AM, Martinez-Larrad MT, Fernandez-

Perez C, Palou A, et al. The Arg64 allele of the beta 3-adrenoceptor gene but not the $3826 \mathrm{G}$ allele of the uncoupling protein 1 gene is associated with increased leptin levels in the Spanish population. Metabolism. 2004;53(11):1411-6. 
medRxiv preprint doi: https://doi.org/10.1101/2021.06.09.21258571; this version posted June 12, 2021. The copyright holder for this preprint (which was not certified by peer review) is the author/funder, who has granted medRxiv a license to display the preprint in perpetuity.

All rights reserved. No reuse allowed without permission.

14. Hayakawa T, Nagai $\mathrm{Y}$, Taniguchi M, Yamashita $H$, Takamura T, Abe T, et al. Phenotypic characterization of the beta3-adrenergic receptor mutation and the uncoupling protein 1 polymorphism in Japanese men. Metabolism. 1999;48(5):636-40.

15. Forga L, Corbalan M, Marti A, Fuentes C, Martinez-Gonzalez MA, Martinez A. [Influence of the polymorphism 03826 A --> G in the UCP1 gene on the components of metabolic syndrome]. An Sist Sanit Navar. 2003;26(2):231-6.

16. Oh HH, Kim KS, Choi SM, Yang HS, Yoon Y. The effects of uncoupling protein-1 genotype on lipoprotein cholesterol level in Korean obese subjects. Metabolism. 2004;53(8):1054-9.

17. Heilbronn LK, Kind KL, Pancewicz E, Morris AM, Noakes M, Clifton PM. Association of -3826 G variant in uncoupling protein-1 with increased BMI in overweight Australian women. Diabetologia. 2000;43(2):242-4.

18. Zhang Y, Meng N, Lv Z, Li H, Qu Y. The gene polymorphisms of UCP1 but not PPAR gamma and TCF7L2 are associated with diabetic retinopathy in Chinese type 2 diabetes mellitus cases. Acta Ophthalmol. 2015;93(3):e223-9.

19. Mori H, Okazawa H, Iwamoto K, Maeda E, Hashiramoto M, Kasuga M. A polymorphism in the 5' untranslated region and a Met229-->Leu variant in exon 5 of the human UCP1 gene are associated with susceptibility to type II diabetes mellitus.

Diabetologia. 2001;44(3):373-6.

20. Herrmann SM, Wang JG, Staessen JA, Kertmen E, Schmidt-Petersen K, Zidek W, et al. Uncoupling protein 1 and 3 polymorphisms are associated with waist-to-hip ratio. J Mol Med (Berl). 2003;81(5):327-32.

21. Shin HD, Kim KS, Cha MH, Yoon Y. The effects of UCP-1 polymorphisms on obesity phenotypes among Korean female subjects. Biochem Biophys Res Commun. $2005 ; 335(2): 624-30$.

22. Montesanto A, Bonfigli AR, Crocco P, Garagnani P, De Luca M, Boemi M, et al. Genes associated with Type 2 Diabetes and vascular complications. Aging (Albany NY). 2018;10(2):178-96. 
medRxiv preprint doi: https://doi.org/10.1101/2021.06.09.21258571; this version posted June 12, 2021. The copyright holder for this preprint (which was not certified by peer review) is the author/funder, who has granted medRxiv a license to display the preprint in perpetuity.

All rights reserved. No reuse allowed without permission.

23. Fukuyama K, Ohara T, Hirota Y, Maeda K, Kuno S, Zenibayashi M, et al. Association of the $-112 \mathrm{~A}>\mathrm{C}$ polymorphism of the uncoupling protein 1 gene with insulin resistance in Japanese individuals with type 2 diabetes. Biochem Biophys Res Commun. 2006;339(4):1212-6.

24. Vimaleswaran KS, Radha V, Ghosh S, Majumder PP, Rao MR, Mohan V. A haplotype at the UCP1 gene locus contributes to genetic risk for type 2 diabetes in Asian Indians (CURES-72). Metab Syndr Relat Disord. 2010;8(1):63-8.

25. Pei X, Liu L, Cai J, Wei W, Shen Y, Wang Y, et al. Haplotype-based interaction of the PPARGC1A and UCP1 genes is associated with impaired fasting glucose or type 2 diabetes mellitus. Medicine. 2017;96(23):e6941.

26. Cha MH, Kang BK, Suh D, Kim KS, Yang Y, Yoon Y. Association of UCP1 genetic polymorphisms with blood pressure among Korean female subjects. J Korean Med Sci. $2008 ; 23(5): 776-80$.

27. de Souza BM, Brondani LA, Bouças AP, Sortica DA, Kramer CK, Canani LH, et al. Associations between UCP1 -3826A/G, UCP2 -866G/A, Ala55Val and Ins/Del, and UCP3 55C/T polymorphisms and susceptibility to type 2 diabetes mellitus: case-control study and meta-analysis. PloS one. 2013;8(1):e54259.

28. Malczewska-Malec M, Wybranska I, Leszczynska-Golabek I, Partyka L, Hartwich J, Jabrocka A, et al. Analysis of candidate genes in Polish families with obesity. Clinical chemistry and laboratory medicine. 2004;42(5):487-93.

29. Schaffler A, Palitzsch KD, Watzlawek E, Drobnik W, Schwer H, Scholmerich J, et al. Frequency and significance of the $A-->G(-3826)$ polymorphism in the promoter of the gene for uncoupling protein-1 with regard to metabolic parameters and adipocyte transcription factor binding in a large population-based Caucasian cohort. Eur J Clin Invest. 1999;29(9):770-9.

30. Cardiovascular diseases (CVDs) [Internet]. 2017 [cited 6 May 2020]. Available from: https://www.who.int/en/news-room/fact-sheets/detail/cardiovascular-diseases-(cvds). 
medRxiv preprint doi: https://doi.org/10.1101/2021.06.09.21258571; this version posted June 12, 2021. The copyright holder for this preprint (which was not certified by peer review) is the author/funder, who has granted medRxiv a license to display the preprint in perpetuity.

All rights reserved. No reuse allowed without permission.

31. Noncommunicable diseases [Internet]. 2018 [cited 6 May 2020]. Available from:

https://www.who.int/news-room/fact-sheets/detail/noncommunicable-diseases.

32. Lunetta KL. Genetic association studies. Circulation. 2008;118(1):96-101.

33. Clarke GM, Anderson CA, Pettersson FH, Cardon LR, Morris AP, Zondervan KT.

Basic statistical analysis in genetic case-control studies. Nature Protocols. 2011;6(2):121-33.

34. Namipashaki A, Razaghi-Moghadam Z, Ansari-Pour N. The Essentiality of Reporting Hardy-Weinberg Equilibrium Calculations in Population-Based Genetic Association Studies.

Cell J. 2015;17(2):187-92.

35. Shi YY, He L. SHEsis, a powerful software platform for analyses of linkage disequilibrium, haplotype construction, and genetic association at polymorphism loci. Cell Res. 2005;15(2):97-8.

36. Li Z, Zhang Z, He Z, Tang W, Li T, Zeng Z, et al. A partition-ligation-combinationsubdivision EM algorithm for haplotype inference with multiallelic markers: update of the SHEsis (http://analysis.bio-x.cn). Cell Res. 2009;19(4):519-23.

37. Kim H-Y. Statistical notes for clinical researchers: Chi-squared test and Fisher's exact test. Restor Dent Endod. 2017;42(2):152-5.

38. Moher D, Liberati A, Tetzlaff J, Altman DG, Group P. Preferred reporting items for systematic reviews and meta-analyses: the PRISMA statement. PLoS Med. 2009;6(7):e1000097.

39. Schwartz DA. Environmental genomics and human health. Giornale italiano di medicina del lavoro ed ergonomia. 2011;33(1):31-4.

40. Yoneshiro T, Ogawa T, Okamoto N, Matsushita M, Aita S, Kameya T, et al. Impact of UCP1 and B3AR gene polymorphisms on age-related changes in brown adipose tissue and adiposity in humans. International Journal of Obesity. 2013;37(7):993-8.

41. Herrmann S-M, Wang J-G, Staessen JA, Kertmen E, Schmidt-Petersen K, Zidek W, et al. Uncoupling protein 1 and 3 polymorphisms are associated with waist-to-hip ratio. Journal of Molecular Medicine. 2003;81(5):327-32. 
medRxiv preprint doi: https://doi.org/10.1101/2021.06.09.21258571; this version posted June 12, 2021. The copyright holder for this preprint (which was not certified by peer review) is the author/funder, who has granted medRxiv a license to display the preprint in perpetuity.

All rights reserved. No reuse allowed without permission.

\section{LIST OF TABLES}

Table 1. Characteristics of the studied population. Age and BMI are presented as median (Q1, Q3)

\begin{tabular}{|c|c|c|c|c|c|}
\hline & Group & (n) / (\%) & $\begin{array}{l}\text { Males / Females } \\
(\mathrm{n})\end{array}$ & Age (years) & $\mathrm{BMI}\left(\mathrm{kg} / \mathrm{m}^{2}\right)$ \\
\hline $\begin{array}{l}\text { Entire } \\
\text { sample }\end{array}$ & $\begin{array}{r}\text { Healthy } \\
\text { CMP }\end{array}$ & $\begin{array}{l}1139 / 50 \\
1144 / 50\end{array}$ & $\begin{array}{l}762 / 528 \\
397 / 521 \\
\end{array}$ & $\begin{array}{l}45(32,54) \\
59(50,65)\end{array}$ & $\begin{array}{l}25.5(23.9,26.9) \\
30.5(27.4,34.2)\end{array}$ \\
\hline Armenia & $\begin{array}{r}\text { Healthy } \\
\text { CMP }\end{array}$ & $\begin{array}{l}105 / 32 \\
226 / 68\end{array}$ & $98 / 128$ & $59(54,64)$ & $29.0(27.2,31.7)$ \\
\hline Greece & $\begin{array}{r}\text { Healthy } \\
\text { CMP }\end{array}$ & $\begin{array}{l}233 / 47 \\
264 / 53\end{array}$ & $\begin{array}{l}131 / 102 \\
125 / 139\end{array}$ & $\begin{array}{l}55(50,65) \\
62(56,68)\end{array}$ & $\begin{array}{l}26.8(24.2,29.9) \\
31.7(28.9,34.5)\end{array}$ \\
\hline Poland & $\begin{array}{l}\text { Healthy } \\
\text { CMP }\end{array}$ & $\begin{array}{l}365 / 59 \\
252 / 41\end{array}$ & $\begin{array}{c}221 / 144 \\
89 / 163\end{array}$ & $\begin{array}{c}32(25,44) \\
62(54.7,67)\end{array}$ & $\begin{array}{l}23.8(22.0,25.6) \\
31.2(29.4,33.8)\end{array}$ \\
\hline Russia & $\begin{array}{r}\text { Healthy } \\
\text { CMP }\end{array}$ & $\begin{array}{l}255 / 45 \\
310 / 55\end{array}$ & $\begin{array}{l}142 / 113 \\
129 / 181\end{array}$ & $\begin{array}{c}46(36.5,54.5) \\
52(40,63)\end{array}$ & $\begin{array}{l}25.9(25.3,26.3) \\
28.9(26.0,34.6)\end{array}$ \\
\hline UK & $\begin{array}{r}\text { Healthy } \\
\text { CMP }\end{array}$ & $\begin{array}{l}181 / 66 \\
92 / 34\end{array}$ & $\begin{array}{c}140 / 41 \\
54 / 38\end{array}$ & $\begin{array}{l}43(30,51) \\
54(48,57)\end{array}$ & $\begin{array}{l}25.7(23.2,29.8) \\
30.7(25.9,38.4)\end{array}$ \\
\hline
\end{tabular}


Table 2. Frequency of genotypes for Ala64Thr in CMP and healthy individuals.

\begin{tabular}{|c|c|c|c|c|c|c|c|}
\hline & \multicolumn{2}{|c|}{ Healthy } & \multicolumn{2}{|c|}{ CMP } & \multirow{2}{*}{ OR $(95 \% \mathrm{Cl})$} & \multirow{2}{*}{ F-test } \\
\hline & & (n) & $(\%)$ & (n) & $(\%)$ & & \\
\hline \multirow{4}{*}{ Total sample } & GG & 944 & 83.39 & 928 & 82.71 & & \\
\hline & GA & 175 & 15.46 & 188 & 16.76 & $1.09(0.87-1.37)$ & 4.03 \\
\hline & AA & 13 & 1.15 & 6 & 0.53 & $0.49(0.19-1.25)$ & \\
\hline & HWE & \multicolumn{2}{|c|}{0.134} & \multicolumn{2}{|c|}{0.284} & & \\
\hline \multirow{4}{*}{ Armenia } & GG & 90 & 86.54 & 164 & 75.58 & & \\
\hline & GA & 14 & 13.46 & 53 & 24.42 & $2.03(1.08-3.83)$ & $\begin{array}{c}5 . / 0 \\
n=0.031\end{array}$ \\
\hline & AA & 0 & 0.00 & 0 & 0.00 & --- & \\
\hline & HWE & \multicolumn{2}{|c|}{0.462} & \multicolumn{2}{|c|}{0.040} & & \\
\hline \multirow{4}{*}{ Greece } & $\mathrm{GG}$ & 184 & 80.70 & 219 & 87.25 & & \\
\hline & GA & 41 & 17.98 & 31 & 12.35 & $0.64(0.39-1.05)$ & $\begin{array}{r}4.20 \\
0-0115\end{array}$ \\
\hline & AA & 3 & 1.32 & 1 & 0.40 & $0.36(0.05-2.46)$ & \\
\hline & HWE & \multicolumn{2}{|c|}{0.679} & \multicolumn{2}{|c|}{0.931} & & \\
\hline \multirow{4}{*}{ Poland } & GG & 304 & 83.29 & 211 & 83.73 & & \\
\hline & GA & 58 & 15.89 & 38 & 15.08 & $0.95(0.61-1.48)$ & $b=0.842$ \\
\hline & AA & 3 & 0.82 & 3 & 1.19 & $1.44(0.32-6.40)$ & \\
\hline & HWE & \multicolumn{2}{|c|}{0.899} & \multicolumn{2}{|c|}{0.394} & & \\
\hline \multirow{4}{*}{ Russia } & $\mathrm{GG}$ & 218 & 85.49 & 257 & 82.90 & & \\
\hline & GA & 34 & 13.33 & 51 & 16.45 & $1.27(0.79-2.02)$ & $\mathrm{D}=0.454$ \\
\hline & AA & 3 & 1.18 & 2 & 0.65 & $0.61(0.12-3.10)$ & \\
\hline & HWE & \multicolumn{2}{|c|}{0.215} & \multicolumn{2}{|c|}{0.758} & & \\
\hline \multirow{4}{*}{ UK } & $\mathrm{GG}$ & 148 & 82.22 & 77 & 83.70 & & \multirow{4}{*}{$\begin{array}{c}1.65 \\
p=0.480\end{array}$} \\
\hline & GA & 28 & 15.56 & 15 & 16.30 & $1.04(0.53-2.05)$ & \\
\hline & AA & 4 & 2.22 & 0 & 0.00 & $0.21(0.01-4.01)$ & \\
\hline & HWE & \multicolumn{2}{|c|}{0.069} & \multicolumn{2}{|c|}{0.395} & & \\
\hline
\end{tabular}

Key: $\mathrm{CMP}=$ cardio-metabolic pathologies; $\mathrm{OR}=$ odds ratio; $\mathrm{HWE}=\mathrm{p}$ value for the Hardy-Weinberg equilibrium. 
Table 3. Body mass index and waist-to-hip ratio [median (Q1,Q3)] across the different UCP1 SNPs for the entire sample as well as across healthy controls and individuals with CMP.

\begin{tabular}{|c|c|c|c|c|c|}
\hline & & \multicolumn{2}{|c|}{ Body mass index } & \multicolumn{2}{|c|}{ Waist-to-hip ratio } \\
\hline \multirow[t]{2}{*}{ SNP } & Genotype & Healthy & CMP & Healthy & CMP \\
\hline & $\mathrm{AA}$ & $25.6(23.5,26.6)$ & $30.3(27.4,34.1)^{1}$ & $0.87(0.81,0.93)$ & $0.97(0.92,1.04)^{1}$ \\
\hline \multirow[t]{2}{*}{ A-3826G } & $A G$ & $25.4(23.6,27.0)$ & $30.7(27.5,34.2)^{1}$ & $0.88(0.81,0.93)$ & $1.00(0.92,1.04)^{1}$ \\
\hline & GG & $26.2(24.1,28.7)^{2,3}$ & $30.8(27.2,33.8)^{1}$ & $0.88(0.80,0.92)$ & $1.00(0.92,1.05)^{1}$ \\
\hline \multirow{3}{*}{$A-112 C$} & $\mathrm{AA}$ & $25.4(23.5,26.7)$ & $30.6(27.5,34.2)^{\top}$ & $0.87(0.81,0.93)$ & $0.98(0.93,1.04)^{1}$ \\
\hline & $A C$ & $25.9(23.7,28.3)^{2}$ & $31.2(27.3,34.2)^{1}$ & $0.88(0.82,0.94)$ & $0.96(0.87,1.02)^{1,2}$ \\
\hline & $\mathrm{CC}$ & $26.3(25.5,27.2)$ & $27.9(27.3,32.5)^{1}$ & $0.87(0.85,0.89)$ & $0.94(0.84,1.00)$ \\
\hline \multirow{3}{*}{ Ala64Thr } & $\mathrm{GG}$ & $25.4(23.4,26.7)^{2,3}$ & $30.5\left(27.4,34.10^{1}\right.$ & $0.87(0.81,0.93)$ & $0.98(0.93,1.04)^{1,3}$ \\
\hline & GA & $26.0(23.8,28.3)$ & $30.5(27.3,33.7)^{1}$ & $0.88(0.82,0.93)$ & $0.97(0.87,1.03)^{1}$ \\
\hline & $\mathrm{AA}$ & $26.3(26.1,27.4)$ & $29.8(27.2,32.7)$ & $0.90(0.84,0.98)$ & $0.92(0.80,1.02)$ \\
\hline \multicolumn{6}{|c|}{ 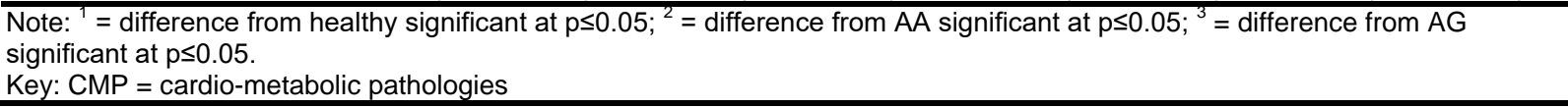 } \\
\hline
\end{tabular}


Table 4. Meta-analysis results for the prevalence and odds ratios of genotypes of the four different SNPs, between healthy and CMP individuals.

\begin{tabular}{|c|c|c|c|c|c|c|}
\hline \multirow{2}{*}{ SNP } & \multirow{2}{*}{$\mathrm{n}$} & \multirow{2}{*}{ Genotypes } & \multicolumn{2}{|c|}{ Prevalence meta-analyses } & \multicolumn{2}{|c|}{ OR meta-analyses } \\
\hline & & & Healthy (\%) & CMP (\%) & OR $(95 \% \mathrm{Cl})$ & $p$ \\
\hline \multirow{3}{*}{$A-3826 G$} & & $\mathrm{AA}$ & 43 & 42 & & \\
\hline & 18568 & AG & 43 & 43 & $1.02(0.96-1.09)$ & 0.46 \\
\hline & & GG & 14 & 15 & $1.06(0.96-1.17)$ & 0.23 \\
\hline \multirow{3}{*}{$A-112 C$} & & $\mathrm{AA}$ & 77 & 78 & & \\
\hline & 6153 & $A C$ & 21 & 21 & $1.07(0.80-1.44)$ & 0.65 \\
\hline & & $\mathrm{CC}$ & 2 & 1 & $0.92(0.65-1.32)$ & 0.67 \\
\hline \multirow{3}{*}{ Ala64Thr } & & GG & 85 & 82 & & \\
\hline & 4984 & GA & 14 & 17 & $1.07(0.91-1.27)$ & 0.41 \\
\hline & & $A A$ & 1 & 1 & $0.64(0.24-1.67)$ & 0.36 \\
\hline \multirow{3}{*}{$A-1766 G$} & & $\mathrm{AA}$ & 64 & 66 & & \\
\hline & 4608 & $A G$ & 30 & 29 & $1.12(0.81-1.55)$ & 0.51 \\
\hline & & $G G$ & 6 & 5 & $1.04(0.53-2.04)$ & 0.90 \\
\hline
\end{tabular}

$95 \% \mathrm{Cl}=95 \%$ confidence intervals; $p=p$ value for the $Z$ test indicating the overall effect in the meta-analysis. 


\section{LIST OF FIGURES}

Figure 1. Prevalence of the studied UCP1 SNP alleles. Note: solid color bars indicate results for individuals with CMP; patterned bars indicate results for healthy persons; * indicates differences from CMP persons significant at $p<0.05$. Key: $\mathrm{MA}=$ meta-analysis, $\mathrm{TS}=$ total sample, $\mathrm{AM}=$ Armenia, $\mathrm{GR}=\mathrm{Greece}, \mathrm{PL}=$ Poland, $\mathrm{RU}=$ Russia, $\mathrm{UK}=$ United Kingdom
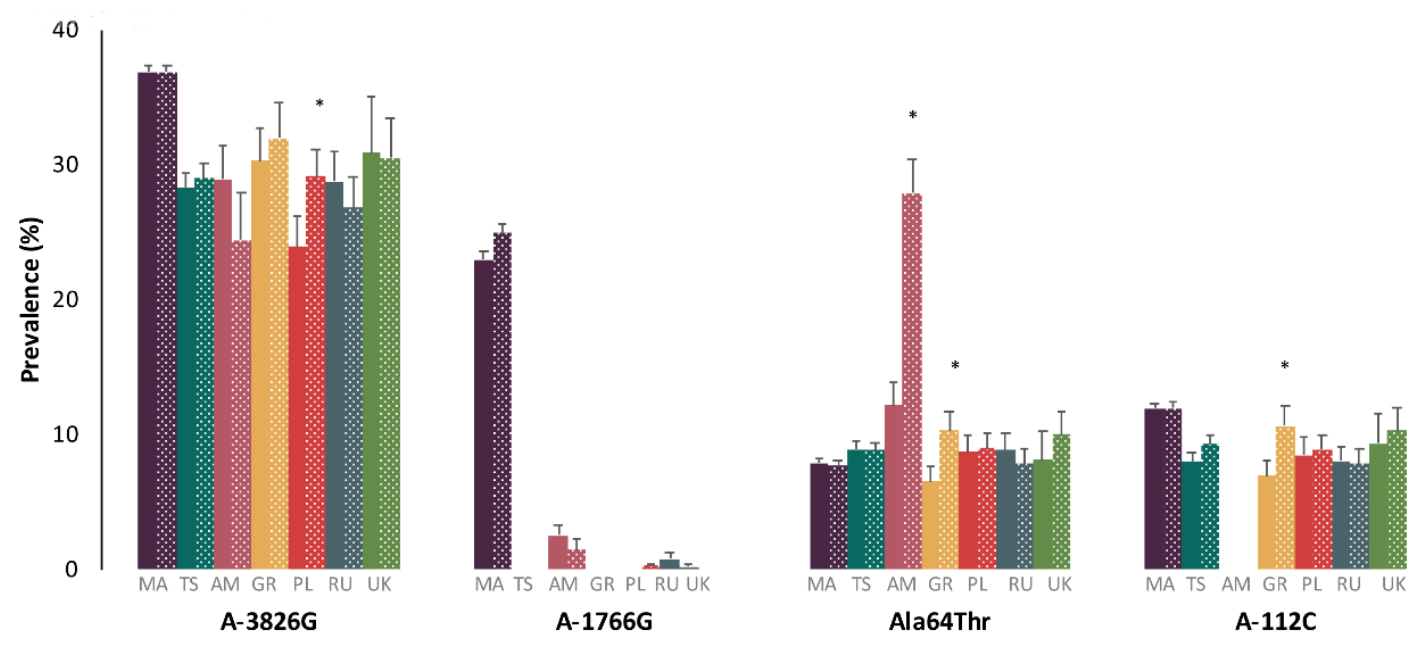